\title{
African Refugee Women and Changing International Priorities: Theoretical and Political Implications
}

\author{
Agnès Callamard
}

In the past five years, there has been a 50 percent increase in the number of refugees worldwide, bringing their estimated total to more than seventeen million at the end of $1990 .^{1}$ In Africa alone, more than 5.4 million people have been identified as refugees in 1990 . The quest for durable solutions has remained a constant dilemma over the years, one whose resolution is complicated by the economic decline that has gripped the African continent for several years now, as well as the UNHCR budget crisis. In recent years, however, the search for durable solutions has undergone two main transformations: the implementation of a refugee assistance and development (RAD) strategy and the organization of massive repatriations.

In the mid-1980s, at a time of budget impasse, economic decline and donor compassion fatigue, international organizations, governments of the countries of first asylum and donors called for a reassessment of international refugee assistance and the effective linkage of refugee assistance and development. Since then, a number of RAD projects and programs have been implemented throughout the world.

A more recent evolution in the search for durable solutions has been massive repatriation movements organized by the international community. The end of the Cold War allowed for the resolution of decades-long domestic or regional wars fuelled by superpower rivalries and for the repatriation of the refugees whoseflight had been generated by these conflicts. The importance of these international developments requires an analysis from a gender perspective and an examination of their effects on refugee women. ${ }^{2}$

Agnès Callamard is a visiting research scholar at the Centre for Refugee Studies.

\section{RAD and Refugee Women}

One of the most important events in refugee assistance and development was the second International Conference on Assistance to Refugees in Africa (ICARA II), which convened in Geneva in 1984 and considered

the continuing need for assistance with a view to providing, as necessary, additional assistance to refugees and returnees in Africa..., the impact imposed on the national economies of the African countries and to provide them with the assistance required to strengthen their social and economic infrastructure so as to enable them to cope with the burden of dealing with large numbers of refugees and returnees. ${ }^{3}$

During the conference, strategies were devised that aimed to (a) "free refugees from dependence on relief" (through self-help activities, food production, participation in local activities to improve economicand social infrastructure, training projects); (b) implement (in addition to the country's ongoing development programs) development-oriented projects that would generate long-term employment for refugees and local people. ${ }^{4}$

The concept of RAD is therefore based on reformulating the design and implementation of refugee assistance so that it encompasses development and provides uprooted populations with durable solutions. With regard to refugee women, the question is whether it benefited them.

ICARA II's resolution and strategies use a gender-neutral language that makes it difficult to analyse how RAD will address the issue of refugee women. This is surprising since, at that time, refugee women were the subject of conferences and research. This indicates that the topic was still marginal to mainstream thinking on refugee and development assistance. It can, however, be argued that refugees as a whole were only by necessity the object of RAD. As shown elsewhere, ${ }^{5}$ while ICARA II aimed to facilitate the search for durable solutions, it was mainly engendered by three considerations: namely institutional (the UNHCR budget crisis), national and local (the mass influx of refugees results in an additional burden on national resources and is likely to produce "hidden losers" 6 among the local population)

The implementation of RAD projects benefited the refugees, as well as the host populations and countries. It could have allowed for additional improvement of the refugee situation, were it not for the lack of resources committed by donor countries, which was especially detrimental to Africa. ${ }^{7}$

While RAD's principles of action eluded the issue of refugee women, a study of ICARA II projects (in Malawi and elsewhere in Africa) indicates that refugee women are often at the forefront of their design and implementation, ${ }^{8}$ but it is also evident that the attention given to refugee women owes more to individual energy and aggressive stewardship than to a real institutional (and international) commitment. In addition to ICARA II, various other RAD projects have been carried out by UNHCR, UN Development Programme and the World Bank, such as PRODERE (Development Programme for Displaced Persons, Refugees and Returnees) in Central America, the joint project (UNHCR/ World Bank/government) for Afghan refugees in Pakistan, or the International Labour Organizations (ILO) Revolving Fund for Ethiopian Refugees in Sudan. ${ }^{9}$ A gender-based review of these and other UN efforts to promote RAD underlines five main trends.

First, the funds devoted to RAD projects for refugee women remain small in comparison with "broader" RAD 
projects such as PRODERE or the Pakistan project. Assistance to refugee women is therefore perceived as necessitating relatively modest capital investment. While it might be true that the immediate goals of such projects (improving health, nutrition, etc.) can be achieved with small capital, it also shows that the issue of refugee women remains peripheral to the funding process and to the interests of donor countries.

Second, policy documents make a claim for refugee women on the basis of their needs and vulnerability (such as sexual and physical abuse, sexual discrimination in the delivery of goods and services).$^{10}$ Projects for refugee women aim to provide solutions to this vulnerability, but the matter is addressed in isolation from its root causes and from the specific problems facing refugee men, such as their inactivity, loss of status, etc.

Third, RAD projects for refugee women are often limited to domestic activities, such as nursing, caring, feeding, etc. (training midwives, for example), or to activities that will benefit the settlement as a whole, such as energy-saving techniques. ${ }^{11}$ Studies of women in development have identified three types of reproduction: biological reproduction, the reproduction of the labour force (daily maintenance of workers) and social reproduction (reproduction of the conditions sustaining a social system). ${ }^{12}$ Projects for refugee women encompass all aspects of reproduction in that they facilitate childbearing activities (through the training of birth attendants) and ease the household workload of women (by providing water facilities, for example). Furthermore, they are based on the assumption that the satisfaction of the needs of refugee women would in turn contribute to an amelioration of the refugee community's welfare, and as such can be associated with a type of social reproduction.

Fourth, there are very few incomegenerating projects specifically for refugee women. They are involved in this type of work through projects for the refugee population as a whole (for example, Ethiopian refugeewomen are receiving loans to establish their own businesses through the ILO revolving funds ${ }^{13}$ ), but the absence of genderdisaggregated data makes it impossible to evaluate the proportion of women benefiting from them. ${ }^{14}$ In the case of income-generating projects, it is evident that positive discrimination is necessary to ensure that refugee women's interests are addressed. ${ }^{15}$

Fifth, to borrow from Deniz Kandiyoti's assessment on assistance to rural women, ${ }^{16} \mathrm{RAD}$ assistance to refugee women and broader RAD projects and policies seem to come from different sources. The former still uses the language of "basic needs" and "self-reliance," whereas the latter distinguish themselves by a strong market orientation. The "development" component of RAD takes different meanings, depending on whether the projects are designed for women or not. To quote from the ICARA II principles for action, it looks as if refugee women ought to "free the refugee population from dependence on relief," while refugee men ought to be engaged in development projects. Given these characteristics, the main question is whether projects for refugee women strengthen or weaken the position of women vis-à-vis refugee men, local authorities and the state of asylum, and whether the focus on essentially domesticactivities emphasize refugee women's vulnerability and subordination. Studies on women in development have shown a positive relationship between women reproductive works and women subordination. Lourdes Beneria has argued that subordination and domination between the sexes is rooted in childbearing, cooking, cleaning and other domestic responsibilities. ${ }^{17}$ She indeed demonstrates that women's biological function has been the basis for their domestic labour and concentration on household work, which, along with the structures of production, explain theirmarginal status and participation in nondomestic activities and ultimately their subordination. ${ }^{18}$

This analysis only applies partially to the study of refugee women. In the context of African refugee communities, the study of gender inequality should take into account a number of variables, such as the state of asylum's refugee policy, the local economic relations of production, the existence of employment alternatives, the potential for attaining self-sufficiency, etc. Some factors should be emphasized. First, studies have suggested that refugees' self-sufficiency and economic integration within a nationbased development process have remained elusive objectives over the years. ${ }^{19}$ Second, as Patricia Daley's study of Burundi refugees in western Tanzania reveals, ${ }^{20}$ gender is only one determining factor in the successful reconstruction of the refugee household. She does confirm Beneria's theoretical analysis by showing that patriarchal tendencies within premigration societies and the male bias of the donor agencies responsible for the resettlement process combine to marginalize women from administrative structures and from participating in Tanzanian society. But she also demonstrates that refugee men and women are subjected to the crises of social reproduction now facing the Tanzanian peasantry. "With the increasingneed to adopt diverse survival strategies, household size and form, particularly the number of adult members and the extended family, have become more relevant criteria." 21

These factors tend to support the theory that projects for refugee women focusing on the productive sphere will meet with little success, given the structural constraints of the African economy. Whether or not African refugee women have access to development projects outside the settlements might not be as crucial a factor as whether or not refugee women participate in the administration of the settlement as equal partners with refugee men, local residents and officials. The study of the functions of refugee women, and of the projects aiming to address their "vulnerability," should be integrated within the broader analysis of the African civil society- and state-making process, and especially of the role of rural communities in fostering or preventing this process. To the extent that these communities are indeed the bases of state power, economic growth and ultimately development, then the reinforcement and/or construction of the function of refugee women as the pillars 
of the refugee communities might not necessarily lead to an increased vulnerability and subordination of women. Yet refugee assistance and development projects for refugee women have failed to translate this possibility into an effective outcome because they have ignored the political dimension of the communities and the creation of their power structures. Indeed, while refugee assistance has assigned refugee women an essential role of insuring the existence and reproduction of the refugee community, it has neglected to strengthen the position of refugee women within the decisionmaking process of the refugee settlement and the host community through, for example, the creation of refugee women's organizations or involving women in the design and implementation of settlement programs, etc. Instead, refugee assistance has promoted refugee men to leadership positions and therefore reinforced the institutional and individual control over women.

\section{Refugee Women and Repatriation}

UNHCR, NGOs and states of first asylum consider voluntary repatriation as the most favoured durable solutions to refugee problems worldwide. The UNHCR has assisted in repatriations throughout the world since its statute was enacted in 1951. In Africa, it organized repatriations to Algeria in 1962, later to Angola, Zimbabwe, Mozambique and more recently to Namibia. It is currently handling repatriation movements to El Salvador, Cambodia, Ethiopia, etc. As far as Mozambicans are concerned, while the prospects for immediate and mass voluntary repatriation still seem bleak, operation plans have already been drafted by the UNHCR. ${ }^{22}$

Stein and Cuny, in their article, "Repatriation under Conflict," have provided a major (and probably unique) conceptualization of the repatriation process. They distinguish between several types of repatriations under conflict, each of them reflecting the political and military circumstances in the country of origin, and between several factors and forces that influence the patterns of repatriations, such as the availability of assistance; whether the repatriation is voluntary, encouraged or forced; whether it involves individuals, small or large collective groups. ${ }^{23}$ They further argue that two main factors interact and drive the repatriation process: the purpose of refugee decision making and the "events in exile," which they further define as ricochet repatriation, relocationstimulated repatriation, community and alienation, and major repatriations. ${ }^{24}$ This analysis provides an important basis for further discussions of repatriation.

The impact of "the events in exile" on refugee women will be mediated by at least three variables:

(a) The nature and intensity of these events -in other words, whether the push factors instigated by the government of asylum, international agencies or refugee organizations allow the refugee community to formulate alternatives to repatriation.

(b) The extent of women's participation in the settlement's decisionmaking process. This refers to the authority and power structures within the settlements and the position of refugee women within these structures.

(c) The extent to which refugee women have been integrated within the local population. A process of differentiation between refugee men and women might occur, depending on whether or not they married local residents. Marriage should not be seen as an incidental factor, but on the contrary as a major variable explaining different patterns of integration and repatriation between refugee men and women. ${ }^{25}$

As Stein and Cuny have shown, the events "at home" can include a wide range of situations, ranging from the country of origin's accession to independence to rival factions taking over areas previously controlled by the government. ${ }^{26}$ Clearly, the repatriation and resettlement process will be influenced by the nature of these events. All of them share one common premise: the necessity to protect refugees during and after repatriation. This is particularly important for refugee women, for flights and resettlement always involve risks of physical abuse. But it is evident that the problems that refugee men and women face upon repatriating to a newly independent country differ fundamentally from the ones they would face if they returned to a country where political conflicts have not been settled. The state is the crucial agency that distinguishes one situation from the other. In one case, the repatriation and resettlement process is engendered by a state that wants to establish its authority and legitimacy over the ex-refugee communities, with international agencies intervening as mediators and facilitators. In the other, the resettlement process is carried out principallyby internationalagencies and the refugees themselves. In both cases, however, the outcome of the repatriation process will be ultimately determined by the economic conditions in the area and country of origin: availability of land, seeds, tools, economy, etc.

There are two types of situations with regard to the impact of the influx of returnees on the agrarian structures and modes of production in the areas where they settle.

(a) Refugees are returning to areas where rural communities were not displaced and where agricultural production did not cease while the refugees were abroad (as in Namibia).

(b) Refugees are returning to areas where, because of continuous fighting, livelihood has been destroyed and agricultural production interrupted. This is characteristic of most refugee situations (Mozambique, Ethiopia, southern Sudan, etc.).

How returnees will adjust to and transform their new environments remain to be investigated. It can be assumed, however, that the repatriation process will influence and transform the preflight agrarian structures and modes of production. It can further be postulated that these changes will affect women returnees women differently' than men. ${ }^{27}$ In addition to the economic structures, other factors will influence 
the outcome of the repatriation process for women returnees.

1. The extent to which the state is formulating and implementing policies to reduce genderinequality and gender discrimination, and to facilitate women's participation in politics.

2. Whether the refugee experience has increased women's subordination (as in the case of Afghan refugee women in Pakistan) or whether it has been a "liberating" force, ameliorating and strengthening women's economic and political position within the settlement and area of asylum).

3. Gender roles and values of the host populations.

The interactive process between economic conditions and production in the returnees' areas, state policies, refugee experiences and cultural values will determine the position of women returnees within the household, the rural community and society at large.

As it has been widely demonstrated, sex roles are subject to change, whether or not such dramaticevents as flights and repatriations are taking place. When they do occur, they further transform the gender division of labour, as well as the productive and reproductive functions of women. Refugee and returnee assistance should not attempt to recreate a social reality more often than not perceived as static and given, but rather facilitate the adjustment to the changes generated by the flight and the resettlement, and accommodate the demands and requirements engendered by these changes.

\section{Conclusion: Refugee Women and the New World Order}

The impact of the New World Order on international humanitarian assistance and on the refugee situation worldwide has been ambivalent. Human rights and democratization are now hailed as the main principles guiding the conduct of foreign policies, but this did not translate into an improvement of the economic, political and social situations of Third World populations. As in the past, more women than men are being displaced because of the conflicts. While some men engage in endless fighting, women and children flee from conflict zones for safe havens that, as in some parts of the Horn of Africa, are few. Although the number of refugees worldwide has increased in the past five years, refugee assistance is suffering from dramatic cutbacks. The global recession has resulted from isolationist trends in industrialized nations, while Third World and former communist countries are now competing over diminishing resources. ${ }^{28}$ Calls for refugee and emergency assistance are left inadequately answered, as in the Horn of Africa. ${ }^{29}$ The African economicand political situations have progressively deteriorated over the past ten years. Africa and refugees worldwide face the risk of being further marginalized. Because of the UNHCR budget crisis, refugee assistance projects, such as the ones in Malawi, are reduced or cancelled. This crisis is bound to have a negative effect on refugee women's projects, which are already suffering from low budgets and their peripheral nature vis-à-vis mainstream development programs. With growing financial constraints, the situation is likely to get worse.

The impact of the end of the Cold War on the root causes of refugee movements worldwide has been similarly equivocal. On one hand, this main cause of conflict in the Third World, and therefore of refugee movements, has been eliminated. The prospect for repatriation in several parts of the world appear more positive. On the other hand, the legacy of superpower rivalries still continue in Somalia, Angola and Mozambique-to cite only a few-in the form of excessive militarization, armed conflicts, constant insecurity, destruction of livelihood, etc. Whenever repatriation is politically possible, it faces serious economic challenges. Although the Cold War has ended, other conflicts continue over national identity. Somalia, eastern Europe and the former Soviet Union now have conflicts that result in massive displacements.

Despite the rhetoric on democratization and human rights, the language of the New World Order has been mainly one of the military and war. What are usually referred to as "male" values dominate global politics and the construction of the New World Order. With the exception of a Palestinian woman representative in the current Middle East peace talks, female figures are noticeably absent from current attempts to reach cease-fire agreements, provide assistance to displaced persons and organize repatriations. In international politics, mediators and conflict makers are male.

Refugee and displaced women are at the bottom of the power pyramid of the New World Order. In an era when nation-states are collapsing, replaced by several smaller entities claiming nationhood, the only voice heard is that of guns fired mostly by men. By virtue of their gender, most refugee women do not participate in the current military attempts to create a new world system of states. By virtue of their status as refugees, they cannot claim any protection besides the one offered (at times reluctantly, as in Somalia) by the international community, and are totally dependent upon humanitarian assistance (which is increasingly reduced because of the global recession), and the generosity of the host populations (which is constrained by rising world poverty and inequality engendered by the international economic system).

\section{Notes}

1. U.S. Committee for Refugees, World Refugee Survey 1991.

2. Length considerations do not allow for an indepth analysis of case studies, so this article will be limited to focusing on some theoretical and political considerations.

3. General Assembly Resolution 37/197 adopted on December 18, 1982.

4. A/AC.96/645 Annex 1 .

5. Agnès Callamard, "Refugee Assistance and Development: But What Sort of Development?"

6. Robert Chambers, "Hidden Losers? The Impact of Rural Refugees and Refugee Programs on Poorer Hosts."

7. Robert Gorman, "Linking refugee Aid and Development in Africa: The International Response."

8. Interview with Deedee Angagaw, ICARA II coordinator, New York, 1992.

9. See especially Refugees, 19-36.

10. Refugee women who are unable to feed, clothe and shelter themselves and their children or who must bribe guards in order to 
obtain firewood, water and other essential goods will be vulnerable to manipulation and to physical and sexual abuse in order to obtain such necessities. See UNHCR, Guidelines on the Protection of Refugee Women, Geneva, July 1992.

11. Ibid. 22.

12. Felicity Edholm, Olivia Harris and Kate Young, "Conceptualizing Women."

13. Ibid. $26-27$

14. It will be interesting to research whether there is a positive relationship between the proportion of men in a refugee settlement and income-generating and developmentoriented projects. In other words, whether the proportion of refugee men vis-à-vis refugee women accounts for the implementation of such activities.

15. For a thorough analysis of refugee women and income generating projects, see the study conducted by the Refugee Policy Group in -Sudan, Pakistan and Costa Rica. Susan Forbes Martin and Emily Copeland, Making Ends Meet? Refugee Women and Income Generation.

16. Deniz Kandiyoti, "Women and Rural Development Policies: The Changing Agenda.

17. Lourdes Beneria, "Reproduction, Production and the Sexual Division of Labour."

18. Ibid.

19. See the study by Barry Stein and Lance Clark, Older Refugee Settlements in Africa.

20. Patricia Daley, "Gender, Displacement and Social Reproduction: Settling Burundi Refugees in Western Tanzania."

21. Ibid. 264.

22. UNHCR branch office in Malawi and UNHCR branch office in Mozambique, Operation Plans: Malawi-Mozambique Repatriation Operation.

23. Stein and Cuny, "Repatriation under Conflict," 18.

24. Ibid. 18-21.

25. Anita Spring, "Women and Men as Refugees: Differential Assimilation of Angolan Refugees in Zambia."

26. Stein and Cuny, "Repatriation under Conflict," 18.

27. A vast number of studies on women in development have demonstrated the relationships between agrarian structures, modes of production and the gender division of labour. See for instance, Esther Boserup, Women's Roles in Economic Development; Lourdes Beneria and Gita Sen, "Accumulation, Reproduction and Women's Role in Economic Development"; Lyne Brydon and Sylvia Chant, Women in the Third World.

28. Robert Gorman, "Global Change and Donor Country Priorities for Refugee and Development Aid in Africa: Hard Choices, Uncertain Future."

29. In September 1991, a UN consolidated interagency appeal was made, requesting U.S. $\$ 400$ million for emergency relief in the Hom of Africa. In February 1992, only $\$ 260$ million was granted, while the financial needs have greatly increased. See Special
Emergency Programme for the Horn of Africa, Consolidated Inter-Agency Appeal, September 1991 and February 1992.

\section{References}

Beneria, Lourdes. 1979. "Reproduction, Production and the Sexual Division of Labour." Cambridge Journal of Economics 3:203-25.

Beneria, Lourdes, and Gita Sen. 1981. "Accumulation, Reproduction and Women's Role in Economic Development: Boserup Revisited." SIGNS 7, no. 2 (Winter): 279-98.

Boserup, Esther. 1970. Women's Role in Economic Development. London, England:George Allen and Unwin Ltd.

Brydon, Lyne, and Sylvia Chant. 1989. Women in the Third World. New Brunswick, New Jersey: Rutgers University Press.

Callamard, Agnès. Forthcoming. "Refugee Assistance and Development: But What Sort of Development?" In Refugee Aid and Development: Theory and Practice, edited by Robert Gorman. Westport, Connecticut: Greenwood Publishers.

Carpenter, Margaret. 1981. "Addressing the Needs of Women Refugees." In World Refugee Survey, 42-44. Washington, D.C.: U.S. Committee for Refugees.

Cerquone, Joseph. 1983. "Repatriation: A Troubled Favored Solution." In World Refugee Survey, 15-19. Washington, D.C.: U.S. Committee for Refugees.

Chambers, Robert. 1986. "Hidden Losers: The Impact of Rural Refugees and Refugee Programs on Poorer Hosts." International Migration Review 20, no. 2 (Summer): 245-63.

Daley, Patricia. 1991. "Gender, Displacement and Social Reproduction: Settling Burundi Refugees in Western Tanzania." Journal of Refugee Studies 4, no. 3:248-66.

Edholm, Felicity, Olivia Harris and Kate Young. 1977. "Conceptualizing Women." Critique of Anthropology 3, no. 9/10:102-30.

Forbes Martin, Susan, and Emily Copeland. 1988. Making Ends Meet? Refugee Women and Income Generation. Washington, D.C.: Refugee Policy Group.

Gorman, Robert. 1990. "Linking Refugee Aid and Development in Africa: The Intemational Response." A paper presented at the international seminar on "Refugees in Africa: Improving Relief Assistance and the Search for Durable Solutions," International Development Research Centre and the Africa Refugee Study Centre, Arusha, Tanzania, July 30-August 4.

1992. "Global Change and Donor Coun. try Priorities for Refugee and Development Aid in Africa: Hard Choices, Uncertain Future." A paper presented at the conference on "Two Worlds: Migrants, Development, Metropolis," Berlin Institute for Comparative Social Research, Berlin, Germany, March 26 29.

Holborn, Louise. 1975. Refugees: A Problem of Our Time. Metuchen, New Jersey: The Scarecrow Press.
International Rescue Committee. 1990. Malawi Program, Quarterly Report, August 15. December 31. New York, New York: International Rescue Committee.

1991. Education and Its Impact on Family Health: Implications for Refugee Programming, March. New York, New York: International Rescue Committee.

1992. Program Report, February. New

York, New York: International Rescue Committee.

Kandiyoti, Deniz. 1990. "Women and Rural Development Policies: The Changing Agenda." Development and Change 21:5-22.

Okeyo, Achola Pala. 1981. "Reflections on Development Myths." Africa Report (MarchApril): 7-10

Rogge, John, and Joshua O. Akol. 1989. "Repatriation: Its Role in Resolving Africa's Refugee Dilemma." International Migration Review 23, no. 2 (Summer): 184-200.

Special Emergency Programme for the Horn of Africa. 1991. Consolidated Inter-Agency Appeal, September. New York, New York: UN Development Programme.

1992. Consolidated Inter-Agency Appeal, February. New York, New York: UN Development Programme.

Spring, Anita. 1979. "Women and Men as Refugees: Differential Assimilation of Angolan Refugees in Zambia." Disasters 3, no. 4:423-28.

Stein, Barry, and Lance Clark. 1985. Older Refugee Settlements in Africa. Washington, D.C.: Refugee Policy Group.

Stein, Barry, and Fred Cuny. 1991. "Repatriation under Conflict." In World Refugee Survey, 1521. Washington, D.C.: U.S. Committee for Refugees.

Tinker, Irene, ed. 1990. Persistent Inequalities, Women and World Development. New York and Oxford: Oxford University Press.

UN Development Fund for Women. 1991. Strategy on Refugees: Meeting the Needs of the Majority-Women. New York, New York: UN Development Fund for Women.

UN High Commissioner for Refugees. 1990. Refugees, no. 8 (November): 19-36.

1991a. "Encourage the Participation and Retention of Mozambican Refugee Girls: Primary Education in Malawi." In Project Proposals, January. 1991b. Operation Plans: MalawiMozambique Repatriation Operation, January. 1991c. "Support and Enhance the Development Contribution of Homecraft Workers Working with Mozambican Refugee Women in Malawi." In Project Proposals, August.

1992. Guidelines on the Protection of Refugee Women. Geneva, Switzerland: UNHCR.

U.S. Committee for Refugees. 1991. World Refugee Survey 1991. Washington, D.C.: U.S. Committee for Refugees.

Women's Commission for Refugee Women and Children. 1989. Malawi Mission, August 9, 1989. New York, New York: Women's Commission for Refugee Women and Children. 